\title{
A Comparison Between the Second-Hand Clothing Consumption of China and Korea
}

\author{
Yealin Kwon ${ }^{1}$ \\ ${ }^{1}$ Zhejiang Sci-Tech University, School of Fashion Design \& Engineering, Hangzhou, China \\ Correspondence: Yealin Kwon, Zhejiang Sci-Tech University, School of Fashion Design \& Engineering, \\ Hangzhou, China. Tel: 82-10-8378-0117. E-mail: roo0117@naver.com
}

Received: February 6, 2021

Accepted: February 20, 2021

Online Published: February 28, 2021

doi:10.5539/ass.v17n3p41

URL: https://doi.org/10.5539/ass.v17n3p41

\begin{abstract}
The purpose of this study is to research and analyze the second-hand platforms in China and Korea. Todays, second-hand trading has evolved and more and more consumers are using it. In the past, most of the users of the second-hand trading market were low-income households, and the current users of the used trading market are the MZ generation. In this reason, feeling the necessity of researching the second-hand trading platform, I analyze it from data of China and Korea. To achieve the purpose of this study, I collect and analyze two big platform of each country "Xianyu" from China and "Secondhand Market" from Korea. We can see how differences in economies, societies and cultures between China and Korea affect second-hand trading platforms. The study compared the trend of second-hand clothing consumption, the major channels of second-hand clothing consumption, the key categories of second-hand clothing consumption, the leading brands of second-hand clothing consumption, the motivations and obstacles of second-hand clothing consumption. I hope this study to develop the second-hand trading platforms around the world.
\end{abstract}

Keywords: China Second-hand trading platform, Korea Second-hand trading platform, Second-hand trading platform analysis, Second-hand trading platform

\section{Introduction}

Nowadays, the people who we call MZ generation tend to value experience more than environment or own, and this consuming trend leads the world market's growing trend. Caused by the development of technology, second-hand trading platform are showing rapid growth and became a major way of shopping for consumer. As MZ generation calls second-hand trading as a smart consumption, the second-hand trading platform in Korea getting bigger and bigger. Since the platform became bigger, user's knowledge level has grown and distrust, which was one of the problems of second-hand trading has improved. Also, many platforms are applying a system which provide mobile phone authentication and reputation management to deal with fraud or fake. As Chinese consumers showing consuming trend which value cost-effectiveness more than save their face, China's second-hand trading market has growing too. Their improvement of consumption capacity and development of technology leads the expansion of their second-hand trading market. 'Seo Yonggu', a professor of Korea 'Suk Myeong women's university', said that in order to recoup the loss from disposable income caused by recession, more people are selling their useful products. He also said that since second-hand trading platforms have grown and people thought second-hand trading is trendy, supply and demand became matches (Shin, 2019). The awareness of second-hand trading has changed to reasonable consumption that reflects individual tendencies and values. Especially, it became one way to show their personality and values directly around MZ generation and this also makes the market bigger (Kim, 2020). In present, Korea's second-hand trading market is presumed to reaches $\$ 17.9$ billion. After the outbreak of the global financial crisis in 2008 , the size of the market has increased more than five times from $\$ 3.61$ billion. Recently, new trend that to buying second-hand which has unique appearance has rapidly shown. Not only young generations, some people who are wealthy enough also prefer to buy unique second-hand rather than new product. This imply that now, buying second-hand products is not just for an efficient consuming, it became one of the ways to show their ability to spend money for items that is rare or expensive. In other words, it became one way to 'Flex' (Yoo et al., 2020).

Today, the number of second-hand trading users in world is increasing. They use second-hand trading platform because it has variety and cheap products. I target top 10 second-hand brands and top 5 items sold in the 
platform in Korea and China and compared it for the study.

Market is where usefulness and money are exchanged. New products that have various kind of pattern and character have strength in reputation, innovation, quality, and selling point. For second-hand product, since products that already used or owned are not useful for owner, but it is useful for others who are willing to buy it. Global research shows that the digital approach helps not only maintain but also increase the trend of generations $\mathrm{X}, \mathrm{Y}$, and $\mathrm{Z}$ to re-commercialize consumer forms. With the introduction of new trading models, the development of new generations of consumers and social media, and protection of the Internet and the environment, the second-hand trading market has gradually increased. Especially for last 40 years, buying second-hand products became a world's trend (Guiot et al., 2010). For example, global sales of second-hand clothes, footwear and ornaments are expected to increase from \$24 billion in 2018 to \$51 billion in 2023 (ThredUP, 2018). According to comparing the study of 'Kim' and 'Jang' in 2015, the major factor that determines what to purchase from buying preference came from their country and gender. Therefore, I research and analyze the world's largest second-hand trading platform based on the background of Korea and China (Kim\&Jang, 2015).

\section{Method}

At first, let's look at the developed second-hand clothing consumption platforms in China and Korea. Secondly, let's look at the types and methods of second-hand clothing consumption platforms in Korea and China. There are two types of second-hand clothing consumption platform process: $\mathrm{B} 2 \mathrm{C}$ (Business to Consumer) and $\mathrm{C} 2 \mathrm{C}$ (Consumer to Consumer). Thirdly, based on the above, I'll look into the top 5 items sold by country based on 'Xianyu' and' Secondhand Market', the largest second-hand clothing consumption platforms in Korea and China. Fourthly, I'll analyze the top 10 brands of second-hand clothing consumer platforms in Korea and China. Finally, I'll survey and analyze on consumer motivations and obstacles in second-hand clothing consumption platforms in Korea and China.

\section{Results}

\subsection{The Trend of Second-Hand Clothing Consumption}

\subsubsection{Leading Investigation on Chinese Second-Hand Trading Platforms}

For long, China has been unable to handle oversupplied inventory products, or has had difficulty handling remaining items due to employment or moving or other reasons. The recent expansion of the second-hand trading market in China is also drawing attention since the online second-hand trading platform is activated. China's first second-hand trading online platform was launched in 2011 and has been growing rapidly ever since. At 2017, the number of online second-hand trading in China reached 40 million reaching $\$ 77.3$ billion and will be 80 million in 2020 reaching exceed $\$ 150.7$ billion. "Xianyu" is China's largest second-hand trading mobile platform site launched by 'Alibaba' in June 2014, and you can simply log in using Taobao and PayPal. in 2019, "Xianyu" has strategy launch took place in Beijing on April 11. According to the announcement, the platform's trading volume has exceeded $\$ 15.4$ billion by 2018, with about 1 million subscribers registering more than 2 million goods(second-hand) every day. As a result, more than 1.4 billion items are on the platform. $61 \%$ of "Xianyu" users are counted as birth in the late 1990s, and more and more young people are using the second-hand trading platform. The platform quickly introduces hot new products and create statistics on expensive electronics and famous brand watches, bags, books and children's toys. China's active second-hand trade is based on huge market demand, and the relevant market will continue to expand. In particular, the online second-hand economy, which integrates the public sector and e-commerce, along with increasing transaction convenience through mobile platforms, is expected to maintain strong growth (Lee, 2019).

\subsubsection{Leading Investigation on Korean Second-Hand Trading Platforms}

By COVID-19 economic cold, the number of people buying and selling second-hand products is increasing. Also new platforms such as the "carrot market" are also growing rapidly. Beyond the thinner wallet, the fun, experience-seeking tendency, and pragmatism of secondhand transactions are rising. Wealth people, millennium generations, and even housewives are falling for the charm of second-hand trading. Like this, as the economic recession continues due to the prolonged COVID-19, second-hand trading is mounting as a new consumption trend. By analyzing this, we can think that second-hand trading has been activated as pragmatic thinking, emphasis on experience values, and ethical consumption flows intertwined. After the global financial crisis in 2008, low growth has continued, and the second-hand trading market has grown around the world. With the prolonged low growth, demand for second-hand products increased rather than new products for economic reasons, and more people tried to raise cash by selling unused items. In 2008, the size of the domestic second-hand trading market was estimated at $\$ 3.61$ billion, but the industry estimates that it has grown to about 
$\$ 18.26$ billion after the global financial crisis as the second-hand trading market gradually grew. Industries expect this market to grow more steeply in the future. This is because, unlike in the past when there were many people who had high reluctance to second-hand products, more and more people became accustomed to second-hand trading. In particular, as the sharing economy has increased since 2018, the perception of other things used has improved a lot This may because It's not just looking for new products, but it's intertwined with the characteristics of second-hand transactions that are used when needed and then sold back when the need is over. Notable thing is the recent change in perspective surrounding second-hand products. second-hand products that looked shabby in the past have recently changed to 'ethical consciousness'. Since there is recognize of that the high-growth consumption patterns of purchasing new products and indiscriminately use them lead environmental damage, second-hand transactions are being recognized as a kind of sustainable ethical consumption. In particular, second-hand clothing (vintage clothing) is considered not only ethical, but also hip (modern fashion) and an expression of personality, and second-hand trading has become a kind of 'meaning out' (expressing political and social beliefs as consumption). It is also noteworthy that they found fun and abilities through second-hand trading consuming. MZ generation (born in the early 1980s, early 2000s) was born in a prosperous era, experienced a variety of experiences, so they treat it important to have experience. They also put interest in second-hand trading since they seeing it as an experience-enhancing consumption. It has recently shifted from looking for second-hand products like hidden gems at the cheapest price to looking for fun. In this experience, consumers sometimes discover their "competence." A consumer psychology professor says "good second-hand products like hidden gems, by experience from finding and trading, consumers feel 'competent' and have fun (Lee,2020)."

\subsection{The Major Channels of Second-Hand Clothing Consumption}

China's second-hand clothing consumption channels include 'Xianyu' and 'Zhuanzhuan', while South Korea's second-hand clothing consumption channels include 'Secondhand Market' and 'Carrot Market'. First, look at the second-hand clothing consumption channel in China. China's second-hand clothing consumption channels are $\mathrm{C} 2 \mathrm{C}$ and $\mathrm{B} 2 \mathrm{C}$, and $\mathrm{O} 2 \mathrm{O}$ is still in preparation.

Xianyu ( $\mathrm{C} 2 \mathrm{C}$ method): The relevant company is Alibaba and operates in a Consumer to Consumer business method. It provides users with a trading platform and does not participate in certain transactions. Services such as product quality inspection and logistics are not offered, and all processes are voluntarily negotiated by users. Chinese users are 300 million, and daily event users reach 30 million. 'Heon-woo' said he plans to open offline second-hand stores in 20 cities over the next three years.

Zhuanzhuan (C2C $\rightarrow \mathrm{C} 2 \mathrm{~B} 2 \mathrm{C}$ method): The related company of '58 Tung Chung', and it has been changed from the Consumer to Business to Consumer business method. In addition to providing users with a trading platform, they actively promote products sold directly on the platform. The number of monthly subscribers in 2020 was 15 million, down by more than 56\% from 34.7 million in 2019 .

I'll analyzed the channels of second-hand clothing consumption platform in China. After examining the channels of the second-hand clothing consumption platform in Korea, we compare and analyze the differences between China and Korea.

Secondary Country ( $\mathrm{C} 2 \mathrm{C}$ method): It is the largest second-hand trading platform in Korea. It operates in a consumer to consumer business way. Currently, the number of members is 23 million and the number of product registrations per day is 390,000 , the largest. For this reason, the age range of users is also large. The coronavirus particularly accelerated the influx of second-hand subscribers and secured 550,000 new members from February to June when the corona spread. The cumulative transaction amount by the third quarter of 2020 is estimated to reach $\$ 3.99$ billion by the end of the year and $\$ 4.92$ billion by the end of the year.

Carrot Market (C2C method): Carrot Market has the meaning of the second-hand trade that can be found near you, and the greatest competitiveness is being able to trade second-hand product in nearby neighborhoods. It operates in a consumer to consumer business method. In September 2020, it had 10 million subscribers and 20 million cumulative downloads. The carrot market is active in direct trading by providing services from the region, also it has overcome the limitations of the existing platform's parcel delivery transaction because it is possible to trade bulky goods without difficulty since it's nearby your home. It can be seen from this that both Korea and China started with $\mathrm{C} 2 \mathrm{C}$ method, but in China, B2C method is increasing. On the other hand, Korea also tried to use the $\mathrm{B} 2 \mathrm{C}$ method, but still prefers the $\mathrm{C} 2 \mathrm{C}$ method.

\subsection{The Key Categories of Second-Hand Clothing Consumption}

Look at the table below (Table 1). As a result of examining the items that are ranked in the top 5 in the 
second-hand clothing consumption platform, in China there are dresses, shoes, jewelry, bags, and cosmetics, in case of Korea, there are children's clothes, pk t-shirts, golf clothes, dresses, and shoes. First, I'll analyze the products that ranked in the top 5 in second-hand consumption apparel platform in China.

Table 1. The key categories of second-hand clothing consumption

\begin{tabular}{ccc}
\hline Ranking & China & Korea \\
\hline No. 1 & One Piece & Children's clothing \\
No. 2 & Shoes & pk T-shirts \\
No. 3 & Accessories & Windbreaker \\
No. 4 & Bags & One Piece \\
No. 5 & Cosmetics & Shoes \\
\hline
\end{tabular}

1. One Piece: Women's clothing is the most common on Chinese second-hand product platforms. One-piece dresses are the largest, and the price range is from low to medium. One-piece dresses were the largest, and prices ranged from low to high-priced.

2. Shoes (Sneakers, Shoes...): Not only Nike and Adidas, but also Gucci and other luxury shoes.

3. Accessories: Cartier, Tiffany \& Co., Swarovski and others. Rings, necklaces, and bracelets are sold in various ways.

4. Bags: There are many kinds, but you can also see many second-hand luxury bags. We have Gucci, LV, etc.

5. Cosmetics: There are the most types of lipstick among cosmetics. There are YSL, MAC, etc.

I analyzed the products that are ranked in the top 5 in the second-hand clothing consumption platform in China. After examining the items that are ranked in the top 5 in second-hand clothing consumption platform in Korea, I compared and analyzed the differences between China and Korea.

1. Children's clothing: According to a survey of Korean second-hand platforms, most of them were children's clothing. Because Children's clothing is waste of money since children are grow up quickly, but the product itself is clean, making it the most suitable second-hand product and popular among consumers.

2. pk T-shirts: pk T-shirts are popular not only for children's clothing but also for women and men's clothing. Although 'Ralph Lauren' is the flagship brand, it sells most of their products in golf wear. I'm not sensitive to fashion, so I've worn it for a long time and its second-hand products are also a popular product.

3. Windbreaker: Typical Nike and Adidas products are found in golf wear. Products that are out of fashion are being actively resold.

4. One Piece: The second-hand platform in Korea, 'Secondhand Market', also has the greatest number of female dresses. One-piece dresses are often worn once or twice so it's usually almost new. It is widely distributed from high-priced products to low-priced products.

5. Shoes: Nike and Adidas, as well as a variety of shoes such as hiking boots and shoes. it is faster to resold it than other products.

If you look at China's second-hand consumer clothing platform, you can see that there are many products related to women. Among them, dress topped the list, indicating that many women are participating in second-hand transactions. Looking at Korea's second-hand consumer clothing platform, there are a variety of items unlike China. In them, children's clothes are notable, and children's clothes, which are easily wasted due to fast-growing children, topped the list. Through this, it can be predicted that many second-hand transaction users in Korea are raising children or more likely to be people with families.

\subsection{The Leading Brands of Second-Hand Clothing Consumption}

Look at the table below (Table 2). This is a comparison of the differences between Chinese and Korean second-hand clothing brands. First, I'll analyze the top ten brands of second-hand consumption apparel platforms in China. 
Table 2. The leading brands of second-hand clothing consumption

\begin{tabular}{ccc}
\hline Ranking & China & Korea \\
\hline No. 1 & Only & Polo Kids \\
No. 2 & Le fame & Bean pole Kids \\
No. 3 & Zimmermann & Daks Kids \\
No. 4 & ZARA & Ralph Lauren \\
No. 5 & Vero moda & Burberry Kids \\
No. 6 & NIKE & Tommy Hilfiger KIDS \\
No. 7 & YSL Cosmetics & NIKE \\
No. 8 & Cartier & Adidas \\
No. 9 & Gucci & Golf wear (Louis Castel) \\
No. 10 & Tiffany \& Co & Women's clothing (COS) \\
\hline
\end{tabular}

1. ONLY: Came to China in 1996, and since the birth of the brand on September 28, 1996, about 1,800 stores in mainland China have spread to more than 300 cities in mainland China, starting with the first store in Beijing. In 2000, when ONLY's brand status was considerable, 'ONLY' has become a leader in many European fashions since the concept of continuing to lead the trend by introducing the definition of 'quick fashion' into the store for the first time. European design with a trendy feel helps bold and independent urban women to express themselves with outfits. Prices range from a minimum of $\$ 9$ to $\$ 540$. Resale prices range from $\$ 3$ to $\$ 170$.

2. LE FAME: A contemporary designer women's clothing brand, founded in 2007 at the Marangoni Design School in Milan, Italy, starting with the old 'Yangok' boutique in Shanghai. The West harmonized to create a feminine Italian trade-off fashion style and blended Shanghai and Milan city images with a variety of materials, colors and heavy industry. LE FAME is about to acknowledging women's identity rather than emphasizing age. With a variety of designs and more human cuts, you can express women in every aspect of your life to complete a unique and differentiated body line. Prices range from a minimum of $\$ 77$ to a maximum of $\$ 700$. Resale prices range from $\$ 23$ to $\$ 154$.

3. Zimmermann: Zimmermann is Australia's most well-known, typical apparel brand with a sexy, intense pedigree, unique color matching, stylish vintage embroidery, and for the first time in his fashion a realistic look. Prices range from $\$ 463$ to $\$ 3800$ minimum. The resale price ranges from $\$ 15$ to $\$ 385$.

4. ZARA: ZARA is a clothing brand which is subsidiary of Inditex Group (stock code ITX) founded in Spain in 1975 specializing in Zara brand clothing. ZARA is the world's third largest and Spain's No. 1 clothing company with over 2,000 fashion chains in 87 countries. Prices range from $\$ 8$ to $\$ 231$. The resale price ranges from $\$ 4$ to $\$ 115$.

5. Vero moda: 'Vero moda' is a famous women's clothing brand of Denmark's largest fashion group 'BESTSELLER'. Since established in 1987, 'Vero moda' has been striving for elegant fashion for modern women around the world, representing the best fashion trends and uniform construction methods. Currently, Veromoda's sales network is in 45 countries. Prices range from a minimum of $\$ 12$ to a maximum of $\$ 540$. The resale price ranges from $\$ 6$ to $\$ 154$.

6. Nike: Nike is an American sportswear brand that produces and sells sneakers, sweatshirts, and sporting goods. It changed its name from Greek mythology in 1972 to the American pronunciation of Nike, and then sold as "JUST DO IT" in 1988, becoming a global brand. Nike's clothing ranges from $\$ 46$ to $\$ 540$, and shoes from $\$ 89$ to $\$ 262$. Resale prices range from $\$ 10$ to $\$ 23$. Limited edition shoes usually cost $\$ 277$.

7. YSL Cosmetics: YSL, short for Yves Saint Laurent. Yves Saint Laurent was founded on August 1, 1936 by 'Yves Saint Laurent', born in Algeria, North Africa, it sells mainly in the fields of fashion, skin care, perfume, bags, and glasses. And accessories. Prices for YSL cosmetics range from a minimum of $\$ 41$ to a maximum of $\$ 88$. Resale prices range from $\$ 7$ to $\$ 80$.

8. Cartier: Cartier is a French watch and jewelry manufacturer founded in 1847 by 'Louis-Fransois Cartier' at '31 Rue Montorgueil' in Paris. In 1874, his son 'Jafar Cartier' took over management, after him, his grandchildren 'Louis Cartier', 'Pir Cartier', and 'Chess Cartier'. By them, 'Cartier' became a global brand. Cartier's products 
range from a minimum of $\$ 771$ to a maximum of $\$ 9000$, and there is no difference between resale and new product prices.

9. Gucci: Gucci is an Italian fashion brand founded by 'Gucci O Gucci' in Florence, Italy in 1921. Gucci products include fashion, leather, shoes, watches, ties, scarves, perfumes, household items and pet products. Gucci pouches range from $\$ 1,200$ to $\$ 2,900$. Gucci's shoes range from $\$ 617$ to $\$ 15,000$. Gucci's clothing prices range from $\$ 540$ to $\$ 6,500$, and there is no difference between the resale price and the new product.

10. Tiffany \& Co: Tiffany \& Co. was founded in New York, USA by the famous jewelry watch brand 'Tiffany'. First known for its silverware, Tiffany became famous for its decoration in 1851, and began as a generation of high-end royals and nobles who entered the jewelry business, setting their own standards for platinum and serving the imperial family. Prices range from a minimum of $\$ 460$ to a maximum of $\$ 8900$. There is no difference between the resale price and the new product price.

I analyzed the products that are ranked in the top 5 in the second-hand clothing consumption platform in China. Now, after examining the items that are ranked in the top 5 in the second-hand clothing consumption platform in Korea, we compare and analyze the differences between China and Korea.

1. Polo Kids: Ralph Lauren's Kids Line, worn by children aged 5-16 years. After 'Lauren' said his wife couldn't buy shirts for her kids, she started making clothes for boys and girls. With the sale of high-quality children's clothing, the historic children's clothing tradition of Ralph Lauren's lifestyle began. Since 1978, polo children's clothing has been expanded to girls, boys, toddlers and babies. Prices range from a minimum of $\$ 500$ to a maximum of $\$ 262$. The resale price ranges from $\$ 15$ to $\$ 46$.

2. Beanpole Kids: Beanpole Kids is a Korean clothing brand and one of Samsung C\&T's representative clothing brands. Beanpole Kids exhibited quality-certified coats with cutting prices by up to $70 \%$ of existing products, increasing cost efficiency. Beanpole Kids mainly targets children aged 7-10 and offers products in 4-5 sizes ranging from $120 \mathrm{~cm}$ to $165 \mathrm{~cm}$. Since online platform has established in 2017, Baby Paul's product price soared from $\$ 54$ to $\$ 185$, and its resale price ranged from $\$ 15$ to $\$ 46$.

3. Daks Kids: A clothing brand established in the UK. However, it was a Japanese company until it transferred ownership of the Japanese brand in 1992. Born in London in 1894, Daks launched a range of products including golf, accessories, children's, men's and women's clothing. One of them, 'Daks Kids' clothing is typically sold between the ages of 3 and 15 and prices soar from $\$ 61$ to $\$ 277$ with Resale prices range from $\$ 18$ to $\$ 46$.

4. Ralph Lauren: Started the tie business in 1967 under the brand name "Polo Fashion" and expanded into luxury men's clothing in 1968 becoming an independent company. For more than 30 years since Paul was founded, Ralph Lauren has not only visualized the lifestyle of the apparel industry, but also reflected the American thinking associated with Polo Ralph Lauren through a unique marketing strategy. Prices range from $\$ 92$ to $\$ 540$. Resale prices range from $\$ 18$ to $\$ 46$.

5. Burberry Kids: In 1988, Burberry launched a kid line for infants and toddlers, and British children also wore Burberry clothes. In 1989, Burberry once again acquired the Royal Warranty mark, proving that it is a popular British brand for men, women and women of all ages. Burberry Kids can be worn from 1 to 16 years old, and prices range from a minimum of $\$ 160$ to a maximum of $\$ 771$ with the Resale prices range from $\$ 46$ to $\$ 108$.

6.Tammy Hilfiger Kids: Founded in 1985, Tommy Hilfiger is a 'Tommy Hilfiger and jean's brand that brings luxury style, quality and value to HILLFIGER collections, men's, women's and children's sweatshirts, denim, accessories and footwear worldwide. Tammy Hilfiger Kids can be worn from 1 to 16 years old and range from a minimum of $\$ 15$ to a maximum of $\$ 200$ The resale price ranges from $\$ 15$ to $\$ 30$.

7. Nike: * (status and characteristics of the top 10 apparel brands in China's second-hand platform sales rate) Same content.

8. Adidas: A German sports brand that founded in 1948, produces and sells athletic shoes, sportswear and sportswear. Adidas developed the world's first soccer shoes with rubber soles and multiple spikes, and expanded its foothold as a global brand by developing various sports-related products such as bags, watches, glasses, and sneakers. Adidas clothing costs between $\$ 23$ and $\$ 385$ and shoes between $\$ 77$ and $\$ 370$ with resale prices range from $\$ 10$ to $\$ 23$ and its Limited-edition shoes usually cost $\$ 385$.

9. Golf Wear (Louis Castel): Louis Castel is a Korean brand established in 2007. Golf clothing ranges from a minimum of $\$ 89$ to a maximum of $\$ 231$ with resale prices range from $\$ 15$ to $\$ 23$.

10. Women's Wear (COS): First launched in London in 2007 and has gradually expanded worldwide. COS is abbreviation of 'Collection of Style'. Compared to H\&M, a low-cost SPA brand favored by young people, the 
price is more than twice as expensive, but it is preferred by those who purchase basic high-quality products with a reasonable price by increasing the quality. COS pursues Timeless and Minimalism. Prices range from a minimum of 26 dollars to a maximum of 308 dollars with resale prices range from $\$ 23$ to $\$ 54$.

By analyzing the brands that entered the top 10 second-hand clothing platforms in China, you can see that there are products more expensive than Korea. You can see that most of the top 10 brands of second-hand clothing platforms in China are luxury brands and are resold by high prices. On the other hand, the top 10 brands on the second-hand clothing platforms in Korea have many children's clothing and general brands, and have a mediocre price. In addition, if Chinese second-hand clothing items are mostly women-related brands, most of Korea's are children's wear and sportswear.

\subsection{The Motivations and Obstacles of Second-Hand Clothing Consumption}

Look at the table below (Table 3). It analyzed the motives and obstacles of consumption of second-hand clothing in China and Korea. First of all, environmental protection appeared in common motives for consumption of second-hand clothing in China and Korea. It shows that both of them prefer eco-friendly products and strive for sustainable consumption. The difference is that the motives for consumption of second-hand clothing in China include limited edition and cost-effectiveness. After they purchase limited edition sneakers and luxury bags, they resell them with a more expensive price when time flows. This is called 'ShoeTech (Shoes + tech)' and 'Chatech $($ Chanel + tech)', and are increasingly showing their expertise. In addition, people born in 1990s who are emerged as a new consumption's main force in second-hand trading, show a tendency to enjoy good products at low prices. In other words, the rapid rise of the second-hand market is relevant with the characteristics of 90s's people which places importance not only on the cost-effectiveness, but also on the psychological satisfaction. Reasonable consumption and vintage are the motives for consuming second-hand clothing in Korea. Consumers who are Millennium and $\mathrm{Z}$ generations show more rational and moral consumption tendencies than previous generations. As they aim for experiential consumption rather than material consumption, they borrow or purchases second-hand products instead of buying new ones, and tries to find products that are on discounts even though he can afford it economically. They prefer products with a 'vintage' sensibility and products that can save time and are practical. Obstacles of second-hand clothing consumption platform in China include quality problems, security problems, and logistics and distribution problems. It is difficult to define product quality itself, and there are many problems with platform supervision, lack of credit system, and fake sneakers and bags. Also, some cases include that though sellers send products, but normal payments have not been received. As a buyer, it is very difficult to judge whether the other end of the transaction is a private seller or, in particular, reseller organization. For the more, the hygiene and safety of second-hand products are often not guaranteed, and product damage that occurs in the delivery process are one of biggest problem of transaction disputes. On the other hand, in Korea, fraud, defective products, and a/s function were selected as obstacles. As the second-hand trading market expands, fraudulent crimes have increased. This is because there are still a classic second-hand fraud tactics that swindler cut the contact after receiving money or that after selling a product that has defect, they don't offer a refund or A/S service.

Table 3. The motivations and obstacles of second-hand clothing consumption

\begin{tabular}{ccc}
\hline Factors & China & Korea \\
\hline \multirow{2}{*}{ Motivations } & environmental protection & environmental protection \\
& limited edition & Reasonable consumption \\
& cost-effectiveness & vintage \\
\hline Obstacles & quality problem & fraud \\
& security problem & defective products \\
& logistics and distribution problems. & a/s function \\
\hline
\end{tabular}

\section{Conclusion}

This study analyzes the second-hand trading platforms in Korea and China, and show the top purchasing products in the second-hand trading platform, the brands of the top purchasing products, and purchase motives and obstacles of people using second-hand trading platforms. According to the results of this study, first, it was found that the current second-hand trading market is different from the past and many people using it with a 
positive perception. Second, in the top 5 items of second-hand trading platforms, Korea had a lot of children's clothing, and China had a lot of women's items. Third, as for the brands that are ranked in the top 10 on the second-hand trading platform, there are many general brands in Korea, while many expensive luxury brands in China. Fourth, as a result of analyzing the motivations and obstacles of the second-hand clothing consumption platform, the motivations for trading second-hand clothing in China were limited edition, cost efficiency, and environmental protection. Obstacles to Chinese second-hand trading include quality issues, security issues, logistics and distribution issues. The results of Korea, environmental protection, pursuit of rational consumption, preference for vintage products, etc are the motives of using second-hand trading, and obstacles include fraud, receipt of defective products, and $\mathrm{A} / \mathrm{S}$ function problems. Based on these results, the significance and implications of the study are as follows. First, there is not much data on existing research on second-hand trading. The second-hand trading platform market is showing greater growth as it recently overlapped with Corona. At this point, this study investigates and analyzes the developed second-hand trading platform market and reveals it in various aspects, and through analysis of purchase motives and purchase obstacles of second-hand trading buyers, it identifies the factor that affects to increase purchases. It is meaningful to present an element that can increase second-hand trading purchases. Second, according to the results of this study, the top 10 brands, top 5 products, and obstacles in motivating second-hand trading are significantly different in each country's platform. This imply that the cultural, social, and economic differences between the two country make the difference of their main second-hand trading brand and purchasing products. This can be used to further expand the second-hand trading platform market. As this study analyzed and researched the largest second-hand trading platforms in Korea and China, the results of the study can't represent all second-hand trading, Also, it is necessary to analyze the sales motives of second-hand sellers. Future studies taking this into account are needed, and studies that consider various variables that can affect second-hand trading platforms with infinite potential for development should also be conducted.

\section{References}

Guiot, D., \& Roux, D. (2010). A second-hand shoppers' motivation scale: Antecedents, consequences, and implications for retailers. Journal of Retailing, 86(4), 355-371. https://doi.org/10.1016/j.jretai.2010.08.002

Kim, C.-H. (2020). MZ Generation's Used Trade Growth. Asian Economy. Retrieved from https://view.asiae.co.kr/article/2020073015345229746

Kim, J.-S., \& Jang, D.-C. (2009). The Purchasing Patterns of University Students in Buying the Winning Products in Korea and China: Focusing on Beverages, Cell Phones and Clothing Products. Korea Open $\begin{array}{lllll}\text { Access } & \text { Journals, } & \text { 27(3), } & \text { Retrieved } & \text { from }\end{array}$ https://www.kci.go.kr/kciportal/landing/article.kci?arti_id=ART001383767

KITA.NET. (2019). Chinese Used Platform Rapidly Growing. Retrieved from https://www.kita.net/cmmrcInfo/ cmmrcNews/overseasMrktNews/overseasMrktNewsDetail.do?nIndex $=18116 \&$ type $=1$

Lee, J.-E. (2020). It's not money that's why you're into second-hand transactions. Money Today. Retrieved from https://news.mt.co.kr/mtview.php?no=2020060422234578475

Shin, H.-C. (2019). Second-hand transaction profits solsol ' Fall into the taste of business. Retrieved from https://www.donga.com/news/article/all/20190907/97318827/1

ThredUP. (2018). ThredUP's Annual Resale Report 2018. Retrieved from https://cf-assets-tup.thredup.com/resale_report/2018/2018-resaleReport

Yoo, S.-M., Jung, H.-Y., \& Lee, J.-E. (2020). Gold Spooners' Buying 10 Times Old Toys, Going to See Used Cars. Money Today. Retrieved from https://news.mt.co.kr/mtview.php?no=2020060422270591740

\section{Copyrights}

Copyright for this article is retained by the author(s), with first publication rights granted to the journal.

This is an open-access article distributed under the terms and conditions of the Creative Commons Attribution license (http://creativecommons.org/licenses/by/4.0/). 